\title{
REACTION OF ISLAMIC STOCK MARKET TO MACROECONOMIC VARIABLES: A STUDY OF INDIA AND INDONESIA
}

\author{
Mohammad Irfan ${ }^{a}$ \\ Salina Kassim ${ }^{b}$ \\ Sonali Dhimmarc \\ Mohd Zahidd \\ Nasrul Fahmi Zaki Fuadie \\ a Department of Management Studies, CMR Institute of Technology, Bengaluru, India \\ ${ }^{\mathrm{b}}$ Institute of Islamic Banking and Finance (IIiBF), International Islamic University Malaysia \\ 'School of Business, Auro University, India \\ ${ }^{\mathrm{d} D e p a r t m e n t}$ of Management, Rajiv Academy for Technology and Management, India \\ eEconomy and Islamic Business, Walisongo State Islamic University, Indonesia \\ Email:drmohdirfan1986@gmail.com ${ }^{a}$; ksalina@iium.edu.my ${ }^{b}$; \\ sonali.dhimmar.mba18@aurouniversity.edu.in ${ }^{c} ;$ mohdzahid2215@gmail.com $^{\text {; }}$; \\ zaki.fuadi@walisongo.ac.id
}

ARTICLE HISTORY
Received:
13 January 2021
Revised
8 April 2021
Accepted:
31 May 2021
Online available:
30 June 2021
Keywords:
BSE Shariah,
Jakarta Islamic Index,
Macroeconomic
Variables,
Panel Regression,
Islamic Stock Market.
*Correspondence:
Name:
Mohammad Irfan
E-mail:
drmohdirfan1986@gmai
I.com

ARTICLE HISTORY

13 January 2021

Revised

8 April 2021

Accepted:

31 May 2021

Online available:

30 June 2021

Keywords:

BSE Shariah Jakarta Islamic Index Macroeconomic

Variables,

Panel Regression, Islamic Stock Market.

*Correspondence:

Name:

Mohammad Irfan

drmohdirfan1986@gmai

l.com

\section{ABSTRACT}

India and Indonesia are among the world-largest democracies, having a strong international presence through involvement in various economic and intergovernmental organizations such as in the E7 countries and G20 countries groups. This study aims to identify the impact of macroeconomic variables on the Islamic stock markets of India and Indonesia. Two Islamic stock market indices are considered: the Indian Bombay Stock Exchange (BSE) Shariah Index and the Indonesian Jakarta Islamic Index (JII). At the same time, the macroeconomic variables are foreign direct investment (FDI), import, export, gross domestic product (GDP), broad money (M3), and exchange rate (ER). The study adopts panel regression analysis on yearly data covering the period from 2011 to 2020. The pooled OLS regression model, fixed effect regression model (FEM), and random effect regression model (REM) have been employed. With the REM model being suggested as the most suitable model through the Hausman test, the results suggest that FDI, export, GDP, and ER have shown positive and statistically significant influence on both the BSE Shariah and JII. It is also shown that the macroeconomic variables of India and Indonesia are heterogeneities in nature and having mean distribution effects. The study's findings suggest that increasing the possibilities of bilateral trade and investment in the sectors such as health and pharmaceuticals, automotive components, information technology, agro products, and tourism between India and Indonesia will go a long way. It is expediting greater economic activities among these two countries. 


\section{INTRODUCTION}

India is the second-largest economy as per population and the third biggest in terms of purchasing power parity in the world (O'Neill, 2021). In terms of economic output, India has the sixth-largest gross domestic product (GDP) and is categorized as a developing country. In the press conference, Finance Minister, Arun Jaitley, commented that India will be the $\$ 5$ trillion by 2024 and $\$ 10$ trillion economies by 2030 (Sharma, 2019). According to Boston Consulting Group - India is expected to be the third-largest consumer economy as its consumption may triple to US\$ 4 trillion by 2025 . Further, it is estimated that India crosses the USA and becomes the second-largest in terms of Purchasing Power Parity (PPP) (India Brand Equity Foundation, 2021). The data published by the World Bank described that India ranks 65 out of 19 in ease of doing business (George, 2020).

Meanwhile, Indonesia is the fourth-largest economy in terms of population and the 10th biggest in purchasing power parity. The country also a member of the G-20 group. It is the big economy in South Asia, which reduces its poverty rate since 1999 to $9.78 \%$ in 2020. Recently, the country was impacted by the Covid-19. However, it was maintaining consistent growth of the economy before the pandemic. The management of Indonesia also took the initiative to overcome the impact of the novel coronavirus. The government of Indonesia declared a $4.3 \%$ of GDP fiscal package to fight with Covid pandemic (The World Bank, 2021a). The economic freedom score of Indonesia is 67.2, which makes the country 54th rank in the index of 2020. The value of goods \& services imports and export is $43 \%$ of GDP. The normal tariff rate of Indonesia is $2.1 \%$. The country is openly welcoming overseas investment, which makes the country attractive, but investors sometimes faced an inconsistent investment code that creates the problem in investment (Index of Economic Freedom, 2020).

Indonesia has a good investment scenario in the ASEAN provision. It has plenty of natural resources and successful manufacturing industry, giving confidence about healthy trade relationship with India's economy (Anand, 2008). India and Indonesia have trade relations since the ancient period. In June 1978, both the country formalized and signed a trade agreement. They are committed to taking all the necessary measures to simplify, strong and differentiate bilateral trade. The first Joint Commission Meeting of IndiaIndonesia was held in September 2003 in Yogyakarta. In the JCM meeting, they are taking a major decision, making a strategy on improvements in trade and economic relations between the countries (India Indonesia Chamber of Commerce, n.d.). As per the record of Indonesia's Central Statistics Agency, noted that in 2016 trade between India-Indonesia was $\$ 12.9$ billion. It would increase by $28.7 \%$ (\$18.13 billion) in 2017 . It includes India's $\$ 14.08$ billion import and $\$ 4.05$ billion export from Indonesia (Livemint, 2019). The data from $\mathrm{FICCl}$ stat that Indonesia's export and India's import include electronic goods, while 
Irfan et al.

chemicals, machines and motor vehicles, textiles, footwear, and sawn timber, pharmaceuticals are the major projects (The Hindu, 2020).

The Consul General of Indonesia, Agus P. Saptono, said that Indonesia is strongly intense to enhance trade and investment bonds with India in the areas like health and pharmaceuticals, automotive components, information technology, agro products, and tourism. Additionally, the Federation of Telangana Chambers of Commerce and Industry (FTCCl) mentioned that there is abundant growth ahead in tourism for both countries. It is also noted that Indonesia has significantly invested in the construction and food processing industry in India (The Hindu, 2020). Livemint (2019) suggested that Ministry of External Affairs spokesperson, Raveesh Kumar, stated India-Indonesia was targeting bilateral trade of $\$ 50$ billion by 2025 . Last year's data shows that bilateral trade deal ready crossed \$20 billion.

This study focuses on the Islamic stock market and macroeconomics variables of India and Indonesia. The objective of the study is to examine the relationship between the Islamic stock market and macroeconomic variables of India and Indonesia. The motive of this study is to know the homogeneity and heterogeneity in the panel data of macroeconomic variables along with BSE Shariah and JII. The reason behind choosing Islamic stock market is it increases awareness among investors towards Islamic stock market. The research between these two countries is found very less or minimal. The selected macroeconomic variables are the major determinants of nation's growth which influence the author to take these variables in the research.

\section{LITERATURE REVIEW}

The present study analyses the impact of the various macroeconomic variable on the BSE Shariah Index and Jakarta Islamic Index (JII) market prices. Therefore, the fulfillment of the previous objective studies related to the present topic is gathered and summarized below.

This study is contributed in the variables of dependent and independent as follows: S\&P BSE 500 Shariah Index is the index of the stock market. The Taqwaa Advisory and Shariah Investment Solutions (TASIS) in collaboration with BSE has launched an index of Islamic on 27th December 2010. The Bombay Stock Exchange and S\&P Dow Jones Indices declared their strategic partnership on 19 February 2013. The S\&P BSE 500 SHARIAH is the first created index from their partnership (S\&P BSE 500 Shariah Index, 2020). JII is the stock exchange index that emerged on 3rd July 2000, listed in the stock exchange of Indonesia. It is also known as Jakarta stock exchange. It is followed the rules and regulation mentioned by Syariah business norms (Indonesia Stock Exchange, n.d.). Foreign direct investment is a monetary source of any country. It refers to the investment by owner of a 
country in another country. It means foreign entity is directly connected for day-to-day operation in the other country (Business Standard, n.d.). Exports refers goods and services manufactured/produced domestically and sold to the other countries. Exports increase the inflow of funds from the countries in the world (Corporate Finance Institute, n.d.). Imports refers goods and services bought by residents' country from rest of the world. It means countries do not manufacture items domestically but outsources from other countries in the world. Imports increase the outflow of funds of the resident country to foreign/exporter country (Corporate Finance Institute, n.d.). GDP is the market value of produced goods and services within the boundaries of the respective country in a given period. The imports and exports are a very important variable in the calculation of GDP. It is also called national income (Corporate Finance Institute, n.d.). Money supply (M3) includes all the money in circulation also the financial liquid products. It is useful in estimating the whole money supply in the entire economy. It helps make monetary policy in a certain variable like to control inflation, growth, liquidity, and consumption (Chen, $2020 b)$. The exchange rate refers to the value of one country's currency exchanged with another country's currency. Every country determines its exchange rate. It could be floating, fixed or hybrid (Chen, 2020a).

A study by Ramli et al. (2021) identifies the cause and effect relationship between shariah and the conventional Indonesian stock market with macroeconomic variables. By applying the autoregressive distributed lag test, bound test, and vector error correction model, the study finds a long-term positive-balanced association of the stock market with macroeconomics variables. Also, there is only one-way causality found between the variables and the stock market (Ramli et al., 2021). Another study by Sieng et al. (2020) analyzed export determinants for Malaysia, Indonesia, Thailand, and the Philippines. The econometric framework like Levin, Lin, Chu applied. The models used in the study namely random, fixed effect, and pooled OLS regression. The period of data was 1981 to 2016. The analyses show exchange rate and import were positively related to export, whereas FDI was negatively for each selected country export (Sieng et al., 2020).

The author finds out the relationship between JII and macro-variables. The data period consists of January 2015 to August 2019. The techniques applied in the study were unit root test, co-integration test, Granger causality test, and ECM. The findings documented that there was both short term \& long-term impact was observed on JII (Yahya, 2000). The study investigates the Islamic stock market of Indonesia. The analyses were based on the Laspeyres formula. The analyses show a significant effect of IPI, industrial production, and inflation rate on the Jakarta Islamic Index (Mashudi et al., 2020). The research explores variation in money supply, exchange rate, interest rate, and its impact on the $\mathrm{JII}$ and conventional stock market. The research technique includes a generalized autoregressive conditional heteroskedasticity model. The study concludes 
that all the selected variables were affected to both the stock exchange (Majid, 2018). The author studied GDP, inflation, BI rate, money supply, exchange rate relation with Jakarta Composite Index (JCI). The data was collected from January 2007 to December 2016. The data analyzed by multiple linear regression analyses. The result showed that there was a significant impact of $\mathrm{BI}$ rate and exchange rate on $\mathrm{JCl}$ (Wahyudi, 2017). The study explores the Indonesian sectorial indices relationship with macro variables. The ordinary least square methodology was used. The monthly data from January 2005 to December 2014 was gathered. The study concludes that there is a significant influence of the exchange rate, inflation rate, and the interest rate on sectoral indices (Sutrisno, 2017). The research scholar analyzes the effect of a macroeconomic variable on the Indonesian Islamic stock market. The data period of the study was January 2007 to October 2012. The vector error regression was applied to time series data. The analyses found that various positive and negative variables impacted JII. Positively affected variables are IPI, DJIEU, DJIMY and negatively affected variables are SBIS, M2, DJIJP, IMUS (Beik \& Fatmawati, 2014). An association between macro variables and the returns of the Indonesian stock market was identified. The variables are namely inflation, money supply, industrial production, interest rates, and exchange rates. There was a co-integration association found between the stock market and selected variables (Harper, 2012).

In the context of India, Irfan and Tanwar (2017) demonstrated that India's sharia and non-sharia stock prices determination. The panel data gathered from the period of 2011 to 2015. The indices were finalized based on market capitalization. The fixed and random effect model was applied. The study found that the random effect tool best suitable for sharia while the fixed effect was useful for non-sharia portfolio (Irfan \& Tanwar, 2017b). The association between sharia and non-sharia indices in Indian stock market was analyzed. The study employs Granger causality model and VECM techniques. The analyses recommend bi-directional interaction between BSE Sensex on Nifty 50 and Nifty Shariah 25 indices. The uni-directional relationship found between on Nifty Shariah 50 and Nifty Shariah 500 index (Irfan \& Tanwar, 2017a). The author examines the Indian Islamic stock market relationship with macro variables. The data collection period includes F.Y 2009 to 2015. The statistical tool such as Augmented Dickey-Fuller Test, PhillipsPerron Test, Johansen Co-integration Test, and Granger causality test applied. The result suggested unidirectional relation of BSE Shariah and Nifty Shariah with macroeconomic variables (Irfan, 2016). The relationship between a macro variable and the Islamic stock exchange of India was evaluated. The factors used in the study, namely BSE Shariah, exchange rate, interest rate, $\mathrm{CPI}$, and money supply. The period for data collection was April 2009 to March 2014. The statistical techniques employed were the ADF test, 
Johansen Cointegrate Test, and VECM. The analyses conclude the notable impact of macro variables on the Indian Islamic stock market (Irfan, 2014).

The researcher tries to found an association between the stock exchange of Egypt and Tunisia with variables like interest rate, exchange rate, $\mathrm{CPI}$, and money supply. The data collection period consists of January 1998-2014. The findings declare association of Egypt and Tunisia stock exchange with macro variables. The Tunisia stock market shows no relationship with CPI (Barakat, 2016). The author evaluates macro variables in short and long run periods for the Islamic stock market of Indonesia and Malaysia. The monthly data of the Jakarta Islamic Index and Malaysia Hijrah Index is collected from January 2006 to December 2010. The selected macro variables are namely Dow Jones Index, exchange rate, Fed rate, interest rate, and inflation. The vector error correction model was used in the study. It was found from the results that, in the long run, Dow Jones Index showed a notable impact on the selected share market. The result of the short-run declared that the Malaysian stock market does not impact selected variables and the Indonesian stock market is influenced by crude oil, exchange rate, and inflation (Antonio et al., 2013).

\section{RESEARCH METHODS}

The research methods are a crucial part of the study. The present research is secondary data based. The sample of the study consist of the Islamic stock market index of two countries namely India and Indonesia. These two countries have trade relation since 1978, both countries have free float trade services and leading in the tourism, which create the wealth of nation. Investors are ready to investment in it. The S\&P BSE 500 Shariah (BSE Shariah) and Jakarta Islamic Index (JII) are selected as representatives of respective countries' stock markets. The macroeconomic variable includes foreign direct investment (FDI), export, import, broad money (M3), gross domestic product (GDP), and exchange rate (ER) are finalized for the study. The period of the research is consisting of 2011 to 2020. Panel data has been used. The data of BSE Shariah is gathered from BSE India (2021) and Jll data is collected from Yahoo Finance (2021). The values of macroeconomic variables are obtained as foreign direct investment, broad money M3, gross domestic product, and exchange rate is from The World Bank (2021b), and exportimports gathered from Ministry of Commerce and Industry (2021). The pooled OLS regression model, fixed effect regression model, and random effect regression model are applied in the study. The equations are derived to conclude the objectives of the study.

$$
\begin{gathered}
\mathrm{Y}_{\mathrm{BSE} \text { Shariah }}=\alpha+\beta 1^{*} \mathrm{FDI}+\beta 2^{*} \text { Export }+\beta 3^{*} \text { Import }+\beta 4^{*} \mathrm{M} 3+\beta 5^{*} \mathrm{GDP}+\beta 6^{*} \mathrm{ER}+\varepsilon \ldots .1 \\
\mathrm{Y}_{\mathrm{BSE} \mathrm{III}}=\alpha+\beta 1^{*} \mathrm{FDI}+\beta 2 * \text { Export }+\beta 3^{*} \text { Import }+\beta 4^{*} \mathrm{M} 3+\beta 5^{*} \mathrm{GDP}+\beta 6^{*} \mathrm{ER}+\varepsilon \ldots .2
\end{gathered}
$$


To achieve the objective of the study, the following hypothesis has been constructed.

$H_{01}$ : There is no significant relationship between India's Islamic stock market and macroeconomic variables

$H_{02}$ : There is no significant relationship between Indonesia's Islamic stock market and macroeconomic variables

$H_{03}:$ All constants are same (homogeneous)

$H_{04}$ : Random effects are consistent and efficient.

Pooled Ordinary Least Squares Regression Model(OLS) consider the entire variable in a single section of data set. In the present study, data is collected for two countries. So, the pooled OLS model would not differentiate between these two-country data and also avoid the cross-section and time-series nature of the data.

Fixed Effect Regression Model (FEM) allows individuality or heterogeneity between numerous cross-sections permitting each cross-section data to have its intercept. In this method, the intercept would be the same over time. The parameters of the model are fixed. The model can be estimated by using dummy variables. Random Effect Regression Model (REM) is also known as the error component model or generalized least square technique. This model also permits heterogeneity among various cross-sections of data. The FEM and REM both allow for heterogeneity and also time-invariant. The difference between FEM and REM is that the particular individual effect is uncorrelated with the independent variables.

Hausman test is the econometric model used to compare two different model estimator's parameter of panel regression data model. It identifies which model is appropriate. Hypothesis:

$H_{0}$ : Random effect regression model is suitable

$\mathrm{H}_{1}$ : Fixed effect regression model is suitable

Alpha value level is $5 \%$. Therefore, if the researcher gets a $p$-value less than 0.05 then the null hypothesis is rejected and the result would be statistically significant. On the other side, if it receives a $\mathrm{p}$-value greater than 0.05 then it is called author fail to reject the null hypothesis and result mentioned as insignificant to the respective study. Finally, it would declare that a $p$-value smaller than $5 \%$ denotes study will be using a fixed-effect model.

\section{RESULT AND ANALYSIS}

This part of the research describes empirical analysis of BSE Sharia and Jakarta Islamic Index relation with foreign direct investment (FDI), export, import, broad money $(\mathrm{M} 3)$, gross domestic product (GDP), and exchange rate (ER). 
Table 1

Pooled Regression of India and Indonesia with Independent Variables

\begin{tabular}{lcccr}
\hline \multicolumn{1}{c}{ Variable } & COEF & S.E. & t-Stats & Prob. \\
\hline C & -6294.8 & 2447.2 & -2.572 & 0.023 \\
FDI & 4.004 & 1.515 & 2.644 & 0.020 \\
EXPORT & 18.1 & 4.104 & 4.411 & 0.001 \\
IMPORT & -1.015 & 1.135 & -0.894 & 0.388 \\
M3 & 95.028 & 62.621 & 1.518 & 0.153 \\
GDP & 170.78 & 105.0 & 1.627 & 0.128 \\
ER & 38.673 & 14.580 & 2.652 & 0.020 \\
\hline R-squared & 0.938 & Mean dep. Var. & 1712.41 \\
Adjusted R2 & 0.910 & S.D. dep. Var. & 1318.57 \\
S.E. of Reg. & 395.379 & AIC criterion & 15.07 \\
SS of resid & 2032218 & SIC criterion & 15.42 \\
Log likelihood & -143.668 & H-Q criterion & 15.13 \\
F-statistic & 33.053 & D-W stat & 1.41 \\
Prob. & 0.000 & & \\
\hline
\end{tabular}

Source: Eviews Output (Data Processed)

Table 1 explains the pooled regression of BSE Shariah and JII with independent variables. The analyses show that the foreign direct investment, export, and exchange rate have a positive significant influence on BSE Shariah and JII stock prices. Further, import, M3, and GDP do not determine BSE Shariah and JII share prices in a significant way. Specifically, the import variable has shown insignificant negative results. The adjusted Rsquared 0.91 implies that the model is best fitted because the independent variable explains $93 \%$ of the dependent variable. The Durbin Watson (DW) value of 1.41 stat that there is a positive autocorrelation between variables. The statistics in the data conclude that all the significant variables have a relationship with stock exchange of India and Indonesia. It includes FDI, export, and ER.

Table 2

Fixed Effect Model of India and Indonesia with Independent Variables

\begin{tabular}{lcccc}
\hline \multicolumn{1}{c}{ Variable } & COEF & S.E. & t-Stats & Prob. \\
\hline C & -4891.3 & 2001.6 & -2.444 & 0.031 \\
FDI & 3.583 & 1.211 & 2.958 & 0.012 \\
EXPORT & 25.0 & 4.023 & 6.220 & 0.000 \\
IMPORT & -1.611 & 0.924 & -1.743 & 0.107 \\
M3 & 42.581 & 52.849 & 0.806 & 0.436 \\
GDP & 184.14 & 83.5 & 2.206 & 0.048 \\
ER & 25.896 & 12.372 & 2.093 & 0.058 \\
\hline
\end{tabular}

Effects Specification

\begin{tabular}{lclc}
\hline \multicolumn{4}{c}{ Effects Specification } \\
\hline R-squared & Cross-section fixed (dummy variables) \\
Adjusted R2 & 0.964 & Mean dep. Var. & 1712.41 \\
S.E. of Reg. & 0.943 & S.D. dep. Var. & 1318.57 \\
SS of resid & 314 & AIC criterion & 14.626 \\
& 1183259 & SIC criterion & 15.024
\end{tabular}




\begin{tabular}{lclc} 
Log likelihood & -138 & H-Q criterion & 14.704 \\
F-statistic & 46.145 & D-W stat & 2.090 \\
Prob. & 0.000 & & \\
\hline
\end{tabular}

Source: Eviews Output (Data Processed)

Table 2 describes the fixed effect model of BSE Shariah and III with independent variables. The figures suggest that foreign direct investment, export, and GDP have a statistically significant positive impact on the share price of BSE Shariah and JII. The other variable import and M3 show statistically insignificant results. It indicates that these two variables do not influence BSE Shariah and JII market prices. The adjusted R2 of 0.90 declare that $91 \%$ of the dependent variable is explained by the independent variable. The DW value of 2.09 suggests that there is a negative autocorrelation between variables. It finalized that FDI, export, and GDP have association with India and the Indonesian stock exchange.

Now researcher has to check which model is best fitted in this panel regression to compare the pooled OLS regression and FEM. There is a substantial difference between the coefficients and significant value. The researcher will check the heterogeneity effects on the OLS and FEM regression. So, the researcher used the restricted F-test.

$$
F=\frac{\left(R^{2} u r-R_{r}^{2}\right) / m}{\left(1-R^{2} u r\right) /(n-k)}
$$

Where $R^{2}$ ur and $R^{2}$ are unrestricted and restricted coefficient of determination, $m$ is the number of parameters omitted from the restricted model ( 2 here), $n$ is the number of observations in the (20), and $\mathrm{k}$ is the number of parameters estimated in the unrestricted regression (here a total of 8). The restricted and unrestricted $R 2$ values are obtained from Tables 1 and 2, respectively.

$$
F=\frac{(0.964-0.938) / 1}{(1-0.964) / 12}=8.67
$$

Therefore, F-stats is greater than the F-critical value, meaning that FEM model is superior to the pooled OLS regression. FEM intercept may differ across the countries but time does not vary countries. 
Table 3

Random Effect Model of India and Indonesia with independent Variables

\begin{tabular}{lcccc}
\hline \multicolumn{1}{c}{ Variable } & COEF & S.E. & t-Stats & Prob. \\
\hline C & -5054.3 & 2234.9 & -2.262 & 0.042 \\
FDI & 3.632 & 1.210 & 3.000 & 0.010 \\
EXPORT & 24.2 & 3.942 & 6.144 & 0.000 \\
IMPORT & -1.542 & 0.922 & -1.673 & 0.118 \\
M3 & 48.672 & 52.496 & 0.927 & 0.371 \\
GDP & 182.59 & 83.5 & 2.188 & 0.048 \\
ER & 27.380 & 12.282 & 2.229 & 0.044 \\
\hline \multicolumn{5}{c}{ Effects Specification } \\
\hline \multicolumn{5}{c}{ S.D. } \\
\hline Cross-section randomo \\
Idiosyncratic random & Parameters & \multicolumn{5}{c}{0.954} \\
\hline \multicolumn{5}{c}{ Weighted Statistics } \\
\hline R-Squared & \multicolumn{5}{c}{ Mean dep. Var. } \\
Adjusted R2 & 0.891 & S.D. dep. Var. \\
S.E. of Reg. & 314.01 & SS of resid \\
F-statistic & 17.63 & D-W stat \\
Prob. & 0.000 & Unweighted Statistics \\
\hline \multicolumn{5}{c}{ Mean dep. Var. } \\
\hline R-squared & 0.415 & D-W stat & 119.1 \\
SS of resid & 19309061 & 785.2 \\
\hline S Output (Data Proces & 1281864 \\
\hline
\end{tabular}

Source: Eviews Output (Data Processed)

Table 3 shows the random effect model of BSE Shariah and JII with independent variables. It is drawn from the table that the majority of independent variables are a statistically significant and positive impact on share prices, namely foreign direct investment, export, gross domestic product, and exchange rate. Meanwhile import is insignificant but negative, M3 is insignificant but positive influence on the Islamic stock price. It identifies that the Indian and Indonesian stock market shows a positive association with FDI, export, GDP, and ER.

The data were analyzed by two models: fixed effect model and random effect model. Based on these model research decide which model is best to fit. To ensure that, the Hausman test will be employed. This particular test will help in determining the suitable model. The Null Hypothesis is listed as:

$H_{0}$ : Random Effect Model is appropriate.

$H_{1}$ : Fixed Effect Model is appropriate. 
Table 4

Hausman Test

\begin{tabular}{llccc}
\cline { 2 - 5 } & Test Summary & Chi-Sq. Statistic & Chi-Sq. d.f. & Prob. \\
\cline { 2 - 5 } & Cross-section random & 2.256 & 6 & 0.56 \\
Source: Eviews Output (Data Processed) & & &
\end{tabular}

Table 4 declared the result of the Hausman test. It indicates that the $p$-value is 0.56 that is greater than $5 \%$ of the alpha level denotes a statistically insignificant $p$-value. It means the researcher fails to reject the null hypothesis. It shows that the random effect model is more suitable, which means that India-Indonesia has common mean value for the intercept. REM estimators are more efficient than the FEM. Estimators are not constant in the random effect model. REM is considered since the number of crosssections is smaller than the number of coefficients to be estimated.

\section{Result Analyses}

The statistics of pooled regression indicate a significant positive association between foreign direct investment, export, the exchange rate with the Islamic stock market of India \& Indonesia. It shows that if FDI in both the country grows will impact positively on the respective Islamic stock market. Export is affected to Indian and Indonesian stock markets. The variation in the exchange rate led to a fluctuation in the stock exchange. In terms of the dollar, a strong dollar not preferable for both the company's investors. It reduces the returns of the stock market. According to data shown in the fixed effect model, foreign direct investment, export, and gross domestic product show a significant positive connection with the Islamic stock market of India and Indonesia. The gross domestic product stat the growth of the country. It would significantly relate to the stock exchange. If growth in both the economy improved, it increases the returns of the selected stock market. The random effect model describes that the Indian and Indonesia Islamic stock market has a substantial positive relationship with foreign direct investment, export, gross domestic product, and exchange rate. Finally, the analyses declare that increase in FDI, exports, GDP, and ER lead to a rise in the returns of the Indian and Indonesian stock exchange. Regarding the previous research, Majid (2018) concludes somewhat a different result compare to the present study. It shows positive relation of exchange rate and broad money with the Indonesian stock market. In the present study, only the exchange rate shows significant association with stock exchanges. The present study shows insignificant negative relation with broad money. Antonio et al. (2013) and Sutrisno (2017) show positive relationship between exchange rate and Indonesian Islamic stock market. Moreover, the rest of the previous studies focuses on different macroeconomic variables. 
Additionally, Hausman test identifies that the random effect model is a good estimator compare to the fixed effect model. REM allows the mixed effect of the data. In this model, variance components have been used. Where hierarchical linear model has worked in the data. It identified all the variables are reacted in the same behavior. It seems the homogeneity in the data, which interpreted the relationship among the variables and Islamic stock market. Irfan and Tanwar (2017b) mentioned similar result with current study. It declares random effcet model is best suitable predictor for Indian Islamic stock market.

At last, it is noted that the Islamic stock market of India and Indonesia shows a significant positive relationship with various macroeconomic variables. They are namely foreign direct investment, export, gross domestic product, and exchange rate. Other variables do not describe the association with the Islamic stock market. It includes import and broad money.

\section{CONCLUSION}

The purpose of the study is to examine the influence of macroeconomic variables on the BSE Shariah and Jakarta Islamic Index. The macroeconomic variables include foreign direct investment (FDI), import, export, gross domestic product (GDP), broad money (M3), and exchange rate. The data period of the study consists of 2011 to 2020 . The panel data regression of the fixed-effect model and random effect model is employed. The fixed model effect and random effect model describes that foreign direct investment, export, broad money (M3), gross domestic product, and exchange rate have a positive influence on BSE Shariah and Jakarta Islamic Index. Only the import has shown a negative effect on respective indices in both the models. However, the notable point is that according to the fixed effect model foreign direct investment, export, and gross domestic product shows a positive and statistically significant impact on BSE Shariah and JII.

Further, the random effect model demonstrates foreign direct investment, export, gross domestic product, and the exchange rate shows a positive and statistically significant influence on BSE Shariah and JII. Additionally, the Hausman test suggested that the random effect model is more appropriate for identifying macroeconomic influence on the Islamic stock market of India and Indonesia. Finally, it would conclude that foreign direct investment, export, and gross domestic product (GDP) play a vital role in the Islamic stock market price variation, namely BSE Shariah India and Jakarta Islamic Index Indonesia.

The study recommends an important macroeconomic variable's impact on the Indian and Indonesian Islamic stock exchange that will be very useful in the Islamic research. In the future, countries like G7, E7, and BRICS would be taken for the study. The other macroeconomic variables also need to be focused on. There is less research in the 
area of the Indian Islamic stock market. Therefore, there is a huge opportunity and need to explore different countries' Islamic stock markets.

\section{ACKNOWLEDGMENT}

I appreciated all the authors for their significant contribution to the present research work. I would also like to thank the government body of India, Indonesia and worldwide institutions for providing statistical data. It includes BSE India, Yahoo Finance, World Bank, Ministry of Commerce, and Industry.

\section{REFERENCES}

Anand, M. (2008). Trends in India-Indonesia Economic Relations. Institute of Peace and Conflicts Studies. http://www.ipcs.org/comm_select.php?articleNo=2650

Antonio, M. S., Hafidhoh, H., \& Fauzi, H. (2013). The Islamic Capital Market Volatility: A Comperative Study between in Indonesia and Malaysia. Buletin Ekonomi Moneter Dan Perbankan, 15(4), 377-400. https://doi.org/10.21098/bemp.v15i4.432

Barakat, M. (2016). Impact of Macroeconomic Variables on Stock Markets: Evidence from Emerging Markets. International Journal of Economics and Finance, 8(1), 195-207. https://doi.org/10.5539/ijef.v8n1p195

Beik, I. S., \& Fatmawati, S. W. (2014). The Impact of International Islamic Stock Market and Macroeconomic Variables Towards Jakarta Islamic Index (JII) [Pengaruh Indeks Harga Saham Syariah Internasional dan Variabel Makro Ekonomi Terhadap Jakarta Islamic Index]. Al-lqtishad: Jurnal Ilmu Ekonomi Syariah, 6(2), 155-178. https://doi.org/10.15408/aiq.v6i2.1228

Business Standard. (n.d.). What is Foreign Direct Investment (FDI). https://www.business-standard.com/about/what-is-fdi

Chen, J. (2020a). Exchange Rate Definition. Investopedia. https://www.investopedia.com/terms/e/exchangerate.asp

Chen, J. (2020b). What is M3? Investopedia. https://www.investopedia.com/terms/m/m3.asp

Corporate Finance Institute. (n.d.). What are Imports and Exports? CFI Edication Inc. https://corporatefinanceinstitute.com/resources/knowledge/economics/imports -and-exports/

George, A. A. (2020). Foreign Trade of India Concepts of International Trade. ClearlAS. https://www.clearias.com/foreign-trade-of-india/

Harper, A. H. (2012). Stock Returns and Macroeconomic Factors: An Examination of The Indonesian Domestic Economy. International Research Journal of Applied Finance, 3(4), 426-434.

https://www.researchgate.net/publication/259533820_Stock_Returns_and_Mac roeconomic_Factors_An_examination_of_the_Indonesian_domestic_economy Index of Economic Freedom. (2020). Indonesia. The Heritage Foundation. https://www.heritage.org/index/country/indonesia 
India Brand Equity Foundation. (2021). About Indian Economy Growth Rate \& Statistics. https://www.ibef.org/economy/indian-economy-overview

India Indonesia Chamber of Commerce. (n.d.). India-Indonesia: Trade and Economic Relations.

Indonesia Stock Exchange. (n.d.). Indeks Saham Syariah. https://www.idx.co.id/idxsyariah/indeks-saham-syariah/

Irfan, M. (2016). A Study of Islamic Stock Indices and Macroeconomic Variables. International Journal of Science, Behavioral, Educational, Business, and Industrial Engineering, 10(7), 2557-2565.

https://www.researchgate.net/publication/318788912_A_Study_of_Islamic_Stoc k_Indices_and_Macroeconomic_Variables

Irfan, M. (2014). Causal Relationship between Macroeconomic Variables and Shariah Index in Emerging Economies: An Empirical Study of India. National Conference on Financial Market, 124-132.

https://www.researchgate.net/publication/344124758_Causal_Relationship_bet ween_Macroeconomic_Variables_and_Shariah_Index_in_Emerging_Economies_ An_Empirical_Study_of_India

Irfan, M., \& Tanwar, S. (2017a). Are Shariah and Non-Shariah Indices Related? Some Empirical Evidence from India. IOSR Journal of Business and Management (IOSR JBM), 19(7), 1-9.

Irfan, M., \& Tanwar, S. (2017b). Fundamental Determinants of Share Price in India: A Comparative Study of Shariah and Non-Shariah Compliant Companies. Pacific Business Review International, 9(8), 58-67. http://www.pbr.co.in/2017/2017_month/Feb/06.pdf

Livemint. (2019). India, Indonesia Set \$50-Billion Trade Target. https://www.livemint.com/news/india/india-indonesia-set-50-billion-tradetarget-by-2025-to-boost-bilateral-ties-1561788142208.html

Majid, M. S. A. (2018). Assesing Volatilities of Monetary Policy and Their Effects on The Islamic and Conventional Stock Markets in Indonesia. Signifikan: Jurnal IImu Ekonomi, 7(2), 161-172. https://doi.org/10.15408/sjie.v7i2.7352

Mashudi, D., Ibrahim, M. A., \& Ilahi, F. (2020). The Effect of Macroeconomic Variables on Sharia Stock Prices in the Jakarta Islamic Index. Proceedings of the 2nd Social and Humaniora Research Symposium (SoRes 2019).

https://doi.org/10.2991/assehr.k.200225.068

Ministry of Commerce and Industry. (2021). Exports-Imports. Ministry of Commerce and Industry. https://tradestat.commerce.gov.in/eidb/default.asp

O’Neill, A. (2021). Total Population of India 2026. Statista. https://www.statista.com/statistics/263766/total-population-of-india/

Ramli, M. R., Masbar, R., Majid, M. S. A., \& Djalil, M. A. (2021). The Analysis Effect of Macroeconomic Variables on Shariah and Conventional Market Share at Indonesia. Palarch's Journal of Archeology of Egypt/Egyptology, 18(1), 34503466. https://www.archives.palarch.nl/index.php/jae/article/view/5366

Sharma, A. (2019). India Economy: An Overview. National Investment Promotion and Facilitation Agency. https://www.investindia.gov.in/team-india-blogs/indian- 
economy-overview

Sieng, L. W., Alimawi, M. Y. S., \& Baharin, R. (2020). Impact of Macroeconomics Variables on Exports in Indonesia, Philippines, Malaysia and Thailand. Journal of Contemporary Issues and Thought (JCIT), 10, 46-57. https://doi.org/10.37134/jcit.vol10.sp.5.2020

Sutrisno, B. (2017). The Impact of Macroeconomic Variables on Sectoral Indices in Indonesia. Etikonomi, 15(1), 195-207. https://doi.org/10.15408/etk.v16i1.4323

The Hindu. (2020). Indonesia Keen on Enhanching Trade Ties with India. The Hindu. https://www.thehindu.com/news/cities/Hyderabad/indonesia-keen-onenhancing-trade-ties-with-india/article32785007.ece

The World Bank. (2021a). The World Bank in Indonesia. World Bank. https://www.worldbank.org/en/country/indonesia/overview

The World Bank. (2021b). World Bank Open Data. World Bank. https://data.worldbank.org/

Wahyudi, R. N. (2017). The Inflence of Macroeconomic Variables toward Jakarta Composite Index on Indonesia Stock Exchange. Jurnal Bisnis, Manajemen, Dan Informatika, 14(2), 131-148. https://doi.org/10.26487/jbmi.v14i2.2164

Yahoo Finance. (2021). Jakarta Islamic Index. https://finance.yahoo.com/quote/\%5EJKII/history/

Yahya, T. (2000). The Effect of Macro Variables on The Jakarta Islamic Index. Asian Journal of Islamic Management, 2(1), 36-45. https://doi.org/10.20885/AJIM.vol2.iss1.art4 